\title{
Synthesis, Characterization and Bioactivities of Some Novel Oxovanadium(IV) Glycinato Complexes
}

\author{
Mohammad K. Islam, DSc \\ Md. Nuruzzaman, MS \\ Rashedul I. Ripon, MS \\ Md. Shalauddin, MS
}

Department of Chemistry, Faculty of Science, Mawlana Bhashani Science and Technology University, Santosh, Tangail-1902, Bangladesh

Foni B. Biswas, MS

Department of Chemistry, Faculty of Science,

University of Chittagong, Chittagong-4331, Bangladesh

\section{Mamun M. Hossain, PhD \\ Mohammad R. Islam, MS \\ Sumaiya Khan, MS}

Department of Chemistry, Faculty of Mathematical and Physical Sciences, Jahangirnagar University, Savar, Dhaka-1342, Bangladesh

Doi: 10.19044/esj.2018.v14n21p410 URL:http://dx.doi.org/10.19044/esj.2018.v14n21p410

\begin{abstract}
The novel oxovanadium(IV) complexes, $\left[\mathrm{V}^{\mathrm{IV}} \mathrm{O}(\mathrm{GlyH})(\mathrm{Gly})\right]^{+} \mathrm{ClO}_{4}^{-}$ $. \mathrm{H}_{2} \mathrm{O}(\mathbf{1}),\left[\mathrm{V}^{\mathrm{IV}} \mathrm{O}(\mathrm{GlyH})(\mathrm{Gly})\right]^{+} \mathrm{NO}_{3}{ }^{-} \cdot \mathrm{H}_{2} \mathrm{O}(\mathbf{2}),\left[\mathrm{V}^{\mathrm{IV}} \mathrm{O}(\mathrm{GlyH})(\mathrm{Gly})\right]^{+} \mathrm{CH}_{3} \mathrm{COO}^{-}$ . $\mathrm{H}_{2} \mathrm{O}(3)$ were synthesized and characterized by FT-IR, UV-Vis and ${ }^{1} \mathrm{H} N M R$ spectroscopic measurements. The cumulative spectroscopic assessment envisaged that, the complexes adopt a square pyramidal structure, in which the two glycine ligands coordinate to vanadium(IV) center in bidentate fashions conforming a homoleptic structure. The amino nitrogen and a carboxylato oxygen atom coordinate the vanadium(IV) center from both sides making a five members chelate by each side. All the complexes are stable in amorphous state and in aerobic and anaerobic solution. Significantly, all the complexes have the antifungal activities against Aspergillus niger and Penicillium notatum but ineffective against Candida tropicalis. No antibacterial activity was observed for the complexes against tested bacteria and unfortunately, they were found cytotoxic against brine shrimp bioassay.
\end{abstract}

Keywords: Oxovanadium(IV); Glycine, Square pyramidal complexes; Bioactivities; Cytotoxicity 


\section{Introduction}

Metal ion-mediated reactions involving nucleic acid constituents and amino acid side chains have been the subject of interest of chemists for several years in versatile investigations. (Garoufis, et al., 1991; Pesch, et al., 1990; Rabindra and Sudhakar, 1990; Rabindra and Raviprakash, 1991; Sigel, et al., 1983; Sabat, et al., 1983). These reactions provide the clue to unfold the nature of such interactions as they serve as models for many metalloenzymatic reactions (Gehad, et al., 2011). Various in vivo studies have shown that biologically active compounds become more bacteriostatic and carcinostatic upon chelation (Chohan, et al., 2006; Husseiny, et al., 2008). Interestingly, amino acids offer excellent ligands for binding to metal ions (Zhang and Lippard, 2003; Kostova, 2006). Complexes of amino acids with some metal ions can be assigned as models to study the potential pharmacodynamic effects of drugs or enhancing the biocompatibility and minimize toxic effects of some metal ions (Grecu, et al., 1986; Asma, et al., 2001). Numerous metal ion amino acid complexes also act as potent antifungal, antibacterial, and anticancer drugs (Orvig and Abrams, 1999; Guo and Sadler, 1999; Bruijnincx and Sadler, 2008). In addition to that, the coordination mode of various metal ions with amino acids have been the topic of discussion for a long period, and the ideas to get the binding modes are not easy to predict for amino acids with large side chain(s), because of different types of donor atoms present in amino acid backbone (Maythalony, et al., 2013). Thus, the interest in transition metal ion-amino acid interactions are increasing (Bhattacharjee, et al., 1990). In this regard, it is important to know the coordination modes of the simple amino acid like Glycine (Gly) ligand with metal ions to understand the reaction mechanism of metalloenzymes (Leary, et al., 1990).

With regard to the biological chemistry of metal ion-glycine complexes, various metal complexes with glycine were extensively studied such as $\mathrm{Mn}(\mathrm{Gly})_{2}, \quad \mathrm{Cu}(\mathrm{Gly})_{2}, \quad \mathrm{Co}(\mathrm{Gly})_{2}, \quad \mathrm{Ni}(\mathrm{Gly})_{2}, \quad \mathrm{Cr}(\mathrm{Gly})_{3} \cdot \mathrm{xH}_{2} \mathrm{O}$, $\left[\mathrm{Cr}(\mathrm{Glu})_{3}\left(\mathrm{H}_{2} \mathrm{O}\right)_{2}\right] \cdot \mathrm{xH}_{2} \mathrm{O}, \quad \mathrm{Cr}(\mathrm{Cys})_{3} \cdot \mathrm{xH}_{2} \mathrm{O}, \quad\left[\mathrm{TiCl}_{3}(\mathrm{Gly})_{3}\right], \quad\left[\mathrm{VCl}_{3}(\mathrm{Gly})_{3}\right]$, $\left[\mathrm{CrCl}_{3}(\mathrm{Gly})_{2} \mathrm{H}_{2} \mathrm{O}\right],\left[\mathrm{FeCl}_{3}(\mathrm{Gly})_{3}\right],\left[\mathrm{CoCl}_{2}(\mathrm{Gly})_{2}\left(\mathrm{H}_{2} \mathrm{O}\right)_{2}\right],\left[\mathrm{NiCl}_{2}(\mathrm{Gly})_{3} \mathrm{H}_{2} \mathrm{O}\right]$ and $\left[\mathrm{CuCl}_{2}(\mathrm{Gly})_{2}\left(\mathrm{H}_{2} \mathrm{O}\right)_{2}\right]$ which have been synthesized and characterized by spectroscopic measurement but not characterized by X-ray crystallography (Williams and Baran, 1997; Temitayo, et al., 2012; Budaiasih, et al., 2013). But in case of silver(I) complex only one literature was available (Nomiya and Yokoyama, 2002). The oxovnadium(IV) glycine system is limited to the solution chemistry studies which has been performed by spectroscopic and potentiometric techniques (Fabian and Nagypal, 1982). The first glycineperoxo complexes of vanadium(V), $\mathrm{NH}_{4}\left[\mathrm{VO}\left(\mathrm{O}_{2}\right)_{2} \mathrm{GlyH}\right] . \mathrm{H}_{2} \mathrm{O}$, $\mathrm{K}\left[\mathrm{VO}\left(\mathrm{O}_{2}\right)_{2} \mathrm{GlyH}\right] \cdot \mathrm{H}_{2} \mathrm{O}$ and $\left[\mathrm{V}_{2} \mathrm{O}_{2}\left(\mathrm{O}_{2}\right)_{3}(\mathrm{GlyH})_{2}\left(\mathrm{H}_{2} \mathrm{O}\right)_{2}\right]$ have been synthesized and characterized by spectroscopic measurement but not 
characterized by X-ray crystallography (Bhattacharjee, et al., 1990). However, as no work has been conducted to develop oxovanadium(IV) complexes with glycine, we were successfully synthesized and characterized the first homoleptic bis(glycinato) oxovanadium(IV) complexes employing various counter anions as well as evaluating the bioactivities of the said complexes.

\section{Experimental section \\ Materials}

Oxovanadium(IV) sulfate, barium perchlorate, barium acetate, $\mathrm{KBr}$ and Cellite-64834 (cellite ${ }^{\circledR}$ R566) were purchased from Sigma-Aldrich, Munich, Germany. Glycine was purchased from Scharlau, Spain. Barium nitrate was purchased from Merck, Germany. The solvents were distilled before use and dried using standard procedures. All chemicals were used without further purification.

\section{Measurements}

FT-IR spectra were taken as $\mathrm{KBr}$ discs in the range $4000-400 \mathrm{~cm}^{-1}$ on a Perkin Elmer Spectrum Two FT-IR spectrometer, Department of Chemistry, Mawlana Bhashani Science and Technology University, Bangladesh. Electronic absorption spectra were recorded on a Perkin Elmer Lambda-25 spectrophotometer under both anaerobic and aerobic conditions, Department of Chemistry, Mawlana Bhashani Science and Technology University, Bangladesh. ${ }^{1} \mathrm{H}$ NMR spectra were measured in DMSO solution on a Bruker AVANCE III $400 \mathrm{MHz}$ NMR instrument and the elemental analyses were carried out on the Vario EL Cube V2.0.7 at Wazed Miah Science Research Centre, Jahangirnagar University, Bangladesh. Chemical shifts are given in ppm relative to tetramethylsilane as an internal reference. Melting points of the complexes were measured on a Stuart SMP10 melting point (range: up to $300{ }^{\circ} \mathrm{C}$ ) apparatus.

Bacterial susceptibility to antimicrobial agents was determined by the disk diffusion. By the standard method of inoculation, an inoculating needle was touched to a single well-isolated colony, and inoculated into $3 \mathrm{~mL}$ of Muller-Hinton Broth (MHB). The broth cultures were then allowed to incubate at $37{ }^{\circ} \mathrm{C}$ for 4 hours to obtain the young culture. The turbidity of actively growing broth cultures was then adjusted to a McFarland 0.5 standard $\left(3 \times 10^{8} \mathrm{CFU} / \mathrm{mL}\right)$. To inoculate the agar medium, a sterile, nontoxic cotton swab was dipped into the standardized suspension, and excess broth was purged by pressing and rotating the swab firmly against the inside of the tube above the fluid level. The swab was then streaked evenly in three directions over the entire surface of the Muller-Hinton Agar (MHA) plate to obtain a uniform inoculum. A final sweep was made of the agar rim with the cotton 
swab. This plate was then allowed to dry for 3 to 5 minutes, before the discs were applied. Antibiotic impregnated discs were then applied to the surface of the inoculated plates with sterile forceps. For the experimental compounds (a: $2 \mathrm{mg} / \mathrm{mL}$, b: $1 \mathrm{mg} / \mathrm{mL}$ and c: $0.5 \mathrm{mg} / \mathrm{mL}$ in concentration), 10 micro-liter of liquid solution of each sample were soaked in filter paper disk. All discs were gently pressed down onto the agar with forceps to ensure complete contact with the agar surface. Within 15 minutes of the application of the disc, the plates were inverted and placed in an incubator at $37{ }^{\circ} \mathrm{C}$. After 16 to 18 hours of incubation, the plates were examined, and the diameter of the zones of complete inhibition was measured to the nearest whole millimeter by a ruler. Here Ciprofloxacin antibiotic disk (Oxoid, UK) was used as standard antibiotics (positive control) and DMSO was used as negative control. Antifungal activity was carried out by following the same method, in Potato Dextrose Agar (PDA) media with 24-48 hours incubation at $26{ }^{\circ} \mathrm{C}$.

Brine shrimp (Artemia salina) larvae were used as indicator animals for preliminary cytotoxicity bioassay (in vitro). This experiment was carried out by following the standard method described by literature (Meyer, et al., 1982). Artificial sea water was prepared by dissolving sodium chloride (3.8 g) in 1 litre distilled water. The salt solution was poured into a glass container and the shrimp eggs were spread and a lamp was illuminated from one side in order to attract hatched shrimps. The hatched shrimps (mature nauplii) were collected after 36 and 48 h of hatching. Experimental solutions of each chemical compounds were prepared in three different concentrations (a: 2 $\mathrm{mg} / \mathrm{mL}$, b: $1 \mathrm{mg} / \mathrm{mL}$ and c: $0.5 \mathrm{mg} / \mathrm{mL}$ ) by using DMSO as solvent. Experimental solutions were then added in a $10 \mathrm{~mL}$ universal bottle containing 10 brine shrimps larvae. The volume was then adjusted to $5 \mathrm{~mL}$ with artificial sea water prepared by dissolving $3.8 \mathrm{~g}$ of sodium chloride in 1 liter of distilled water. Cyclophosphamide was used as standard positive control drug whereas DMSO and artificial sea water as negative control. The number of surviving larvae was determined after 4 and 8 hours and the percentage mortality was determined by comparing the mean surviving larvae of the tests and the control.

\section{Synthesis}

Syntheses of $\left[\mathrm{V}^{I V} \mathrm{O}(\mathrm{GlyH})(\mathrm{Gly})\right]^{+} \mathrm{ClO}_{4}^{-} \cdot \mathrm{H}_{2} \mathrm{O}(1),\left[\mathrm{V}^{I V} \mathrm{O}(\mathrm{GlyH})(\mathrm{Gly})\right]^{+} \mathrm{NO}_{3}^{-}$ . $\mathrm{H}_{2} \mathrm{O}(2)$ and $\left[\mathrm{V}^{I V} \mathrm{O}(\mathrm{GlyH})(\mathrm{Gly})\right]^{+} \mathrm{CH}_{3} \mathrm{COO}^{-} \cdot \mathrm{H}_{2} \mathrm{O}(3)$

Oxovanadium(IV) sulfate $(0.4890 \mathrm{~g}, 3.0 \mathrm{mmol})$ was dissolved in 12 $\mathrm{cm}^{3}$ of deaerated water. To this solution $\mathrm{Ba}\left(\mathrm{ClO}_{4}\right)_{2}(1.0090 \mathrm{~g}, 3.0 \mathrm{mmol})$ $\left[\mathrm{Ba}\left(\mathrm{NO}_{3}\right)_{2}(0.7840 \mathrm{~g}, 3.0 \mathrm{mmol})\right.$ in case of the synthesis of compound 2 and $\mathrm{Ba}\left(\mathrm{CH}_{3} \mathrm{COO}\right)_{2}(0.7660 \mathrm{~g}, 3.0 \mathrm{mmol})$ in case of the synthesis of compound 3 respectively] was added and the mixture was stirred at ambient temperature $\left(30 \pm 2{ }^{\circ} \mathrm{C}\right)$ for 2 hours. Barium sulfate precipitated was filtered off using 
cellite-64834 (cellite®R566). The obtained blue filtrate was deaerated and then saturated with argon. Aqueous solution $\left(12 \mathrm{~cm}^{3}\right)$ of glycine $(0.6757 \mathrm{~g}, 9.0$ $\mathrm{mmol}$ ) was added to the filtrate in an argon atmosphere. The $\mathrm{pH}$ of the mixture was observed to be 3.27 (the $\mathrm{pH}$ was 2.94 for the synthesis compound 2 and 3.27 for the synthesis of compound 3 respectively). The deep blue solution obtained was evaporated to some extent and allowed to stand at ambient temperature $\left(30 \pm 2{ }^{\circ} \mathrm{C}\right)$. After four days, the deep blue colored solution is changed to green color. The green product deposited was filtered off and argon-dried as well as stored in a vacuum desiccator over silica gel for further drying. Caution was taken for the reproduction of the complex as perchlorate salts of metal complexes are potentially explosive (Islam, et al., 2011)

$\left.\boldsymbol{V}^{I V} \mathrm{O}(\mathrm{GlyH})(\mathrm{Gly})\right]^{+} \mathrm{ClO}_{4}^{-} . \mathrm{H}_{2} \mathrm{O}(\mathbf{1})$ : Yield: $68 \%$. m.p.:>300 ${ }^{\circ} \mathrm{C}$. Anal. Found: C, $14.51 ; \mathrm{H}, 2.42 ; \mathrm{Cl}, 10.68 ; \mathrm{N}, 8.41 \% ; \mathrm{O}, 48.46 \%$. Calcd. for $\mathrm{C}_{4} \mathrm{H}_{8} \mathrm{ClN}_{2} \mathrm{O}_{10} \mathrm{~V}$ : C, $14.54 ; \mathrm{H}, 2.44 ; \mathrm{Cl}, 10.73 ; \mathrm{N}, 8.48 ; \mathrm{O}, 48.41 \%$.

[ $\left.\mathrm{V}^{\mathrm{IV}} \mathrm{O}(\mathrm{GlyH})(\mathrm{Gly})\right]^{+} \mathrm{NO}_{3} \cdot \mathrm{H}_{2} \mathrm{O}$ (2): Yield: $72 \%$. m.p.:>300 ${ }^{\circ} \mathrm{C}$. Anal. Found: C, 16.44; H, 2.64; N, 14.36; O, 49.24\%. Calcd. for $\mathrm{C}_{4} \mathrm{H}_{8} \mathrm{~N}_{3} \mathrm{O}_{9} \mathrm{~V}$ : C, 16.39; $\mathrm{H}$, $2.75 ; \mathrm{N}, 14.34 \%$.

[V $\left.{ }^{I V} \mathrm{O}(\mathrm{GlyH})(\mathrm{Gly})\right]^{+} \mathrm{CH}_{3} \mathrm{COO}^{-} \cdot \boldsymbol{H}_{2} \mathrm{O}$ (3): Yield: $75 \%$. m.p.:>300 ${ }^{\circ} \mathrm{C}$. Anal. Found: C, 24.80; H, 3.85; N, 9.62; O, 44.13\%. Calcd. for $\mathrm{C}_{6} \mathrm{H}_{11} \mathrm{~N}_{2} \mathrm{O}_{8} \mathrm{~V}$ : C, 24.84; H, 3.82; N, 9.66; O, 44.12\%.

\section{Results and discussion Spectroscopic properties}

Table 1 describe the infrared spectra of the complexes (1, 2 and 3 ) which exhibit $v \mathrm{C}-\mathrm{H}$ bands at around 2960-2963 $\mathrm{cm}^{-1}, v \mathrm{C}-\mathrm{N}$ bands at around $1180-1263 \mathrm{~cm}^{-1}$ and the $v \mathrm{C}-\mathrm{O}$ bands at around $1328-1344 \mathrm{~cm}^{-1}$. The observed frequencies $v_{\text {asy }}\left(\mathrm{COO}^{-}\right)$was at $1632 \mathrm{~cm}^{-1}$ and the $v_{\mathrm{sy}}\left(\mathrm{COO}^{-}\right)$at $1440 \mathrm{~cm}^{-1}$ are fairly in good agreement with the literature (Temitayo, et al., 2012). The absence of the uncoordinated $v \mathrm{COOH}\left(1730-1775 \mathrm{~cm}^{-1}\right)$ in the IR spectra indicate a clue for the coordination of the ligands to metal ions through the carboxylate anions (Negoiu, et al., 2005). The bands assigned due to the $v \mathrm{~V}$ $\mathrm{N}$ at $552-553 \mathrm{~cm}^{-1}$ are also fairly resembling to the literature (Temitayo, et al., 2012). The participation of the lone pairs of electrons on the $\mathrm{N}$ of the amino group in the ligand to the metals is supported by this band frequency (Osunlaja, et al., 2009). Chidambaram et al. (1970) observed the chelation of the vanadium(IV) by the amino and carboxylate groups, while Di Bernado et al. (1988) have found that glycine seems to behave as a monodentate ligand. Though glycine can be coordinated to $\mathrm{VO}^{2+}$ ion in both monodentate or a bidentate fashions with the variations in function of $\mathrm{H}^{+}$concentrations, (Tomiyasu and Gordon, 1973; Fabian and Nagypal, 1982) our present observation supports the later one. The characteristic bands due to $v \mathrm{~V}=\mathrm{O}$ appeared at 983-991 $\mathrm{cm}^{-1}$ are suggestive of square pyramidal geometries 
around vanadium (Sharma, 2013; Islam, et al., 2011; Sharma, S. and Sharma, N., 2013; Amit, et al., 2010; Agarwal, et al., 1994). The -NH stretching frequency at around $3170-3178 \mathrm{~cm}^{-1}$ reduced on coordination, attributable to the reduction in bond order on coordination (Nakamoto, 2009). All the three complexes show $v \mathrm{OH}$ stretching bands at around $3424-3432 \mathrm{~cm}^{-1}$ and $v \mathrm{H}-\mathrm{OH}$ bending bands at around 1624-1632 $\mathrm{cm}^{-1}$ which eventually indicate the presence of lattice water molecule The $\mathrm{Cl}-\mathrm{O}$ stretching for the perchlorate anion for the complex $\left[\mathrm{V}^{\mathrm{IV}} \mathrm{O}(\mathrm{GlyH})(\mathrm{Gly})\right]^{+} \mathrm{ClO}_{4}^{-} \cdot \mathrm{H}_{2} \mathrm{O}$ (1) appeared at 1121 and $614 \mathrm{~cm}^{-1}$ The perchlorate group is ionic in the complex, since there is no splitting of the perchlorate band around $1100 \mathrm{~cm}^{-1}$ (Islam, et al., 2011; Miller and Wilkins, 1952; Ackarmann, 1970). The IR spectrum for the complex $\left[\mathrm{V}^{\mathrm{IV}} \mathrm{O}(\mathrm{GlyH})(\mathrm{Gly})\right]^{+} \mathrm{NO}_{3}{ }^{-} \mathrm{H}_{2} \mathrm{O}$ (2) exhibits bands at 772 and $1382 \mathrm{~cm}^{-1}$ support the presence of an ionic nitrate (Miller and Wilkins, 1952; Ackarmann, 1970) and band at $1598 \mathrm{~cm}^{-1}$ is assigned for the presence of acetate ion for the complex $\left[\mathrm{V}^{\mathrm{IV}} \mathrm{O}(\mathrm{GlyH})(\mathrm{Gly})\right]^{+} \mathrm{CH}_{3} \mathrm{COO}^{-} \cdot \mathrm{H}_{2} \mathrm{O}(3)$.

Table 1. IR spectral data* $\left(\mathrm{cm}^{-1}\right)$ for the complexes.

\begin{tabular}{|c|c|c|c|c|c|c|c|c|c|c|c|}
\hline $\begin{array}{c}\text { Complex } \\
\text { No. }\end{array}$ & $v \mathrm{C}-\mathrm{H}$ & $v \mathrm{C}-\mathrm{N}$ & $v \mathrm{C}-\mathrm{O}$ & $v \mathrm{~N}-\mathrm{H}$ & $v \mathrm{COO}$ & $\begin{array}{c}v \mathrm{~V}= \\
\mathrm{O}\end{array}$ & $\nu \mathrm{OH}$ & $\begin{array}{l}v \mathrm{H}- \\
\mathrm{OH}\end{array}$ & $v \mathrm{~V}-\mathrm{O}$ & $v \mathrm{~V}-\mathrm{N}$ & Other bands \\
\hline 1 & $\begin{array}{c}2963 \\
\mathrm{~s}\end{array}$ & $\begin{array}{c}1263 \\
\mathrm{~m}\end{array}$ & $\begin{array}{c}1328 \\
w\end{array}$ & $\begin{array}{c}3178 \\
\text { vs }\end{array}$ & $\begin{array}{l}1632 \mathrm{~m}, \\
1440 \mathrm{~m}\end{array}$ & $\begin{array}{c}983 \\
\mathrm{~m}\end{array}$ & $\begin{array}{l}343 \\
2 \mathrm{~s}\end{array}$ & $\begin{array}{c}1638 \\
\mathrm{~s}\end{array}$ & $\begin{array}{c}690 \\
w\end{array}$ & $\begin{array}{l}553 \\
v w\end{array}$ & $\begin{array}{c}1121 \mathrm{vs}, 614 \\
\mathrm{~s}, \\
v \mathrm{ClO}_{4}\end{array}$ \\
\hline 2 & $\begin{array}{c}2960 \\
\mathrm{~s}\end{array}$ & $\begin{array}{c}1221 \\
\mathrm{~m}\end{array}$ & $\begin{array}{c}1344 \\
w\end{array}$ & $\begin{array}{c}3168 \\
\mathrm{~s}\end{array}$ & $\begin{array}{l}1635 \mathrm{~m} \text {, } \\
1401 \mathrm{~m}\end{array}$ & $991 \mathrm{~s}$ & $\begin{array}{c}342 \\
4 \mathrm{~s}\end{array}$ & $\begin{array}{c}1624 \\
s\end{array}$ & $\begin{array}{c}692 \\
w\end{array}$ & $\begin{array}{l}553 \\
\text { vw }\end{array}$ & $\begin{array}{c}772 \mathrm{~m}, 1382 \\
\mathrm{vs}, \\
v \mathrm{NO}_{3}\end{array}$ \\
\hline 3 & $\begin{array}{c}2962 \\
\mathrm{~s} \\
\end{array}$ & $\begin{array}{c}1180 \\
\mathrm{~m}\end{array}$ & $\begin{array}{c}1329 \\
\mathrm{~W}\end{array}$ & $\begin{array}{c}3170 \\
\mathrm{~s} \\
\end{array}$ & $\begin{array}{l}1625 \mathrm{~m}, \\
1406 \mathrm{~m}\end{array}$ & $984 \mathrm{~s}$ & $\begin{array}{c}343 \\
1 \mathrm{~s} \\
\end{array}$ & $\begin{array}{c}1632 \\
\mathrm{~s} \\
\end{array}$ & $\begin{array}{c}691 \\
\mathrm{~W}\end{array}$ & $\begin{array}{l}552 \\
\text { vw }\end{array}$ & $\begin{array}{c}1598 \mathrm{~m} \\
v \mathrm{CH}_{3} \mathrm{COO}\end{array}$ \\
\hline
\end{tabular}

*vs, very strong; s, strong; m, medium; w, weak; vw, very weak.

The visible absorption spectra of all the complexes were observed in DMSO solution under anaerobic condition are shown in Figure 1. The solution $\mathrm{pH}$ were approximately 4.84. Two absorption bands were observed for all the complexes at around 780-800 $\mathrm{nm}$ and 595-609 $\mathrm{nm}$ due to d-d transition which are the characteristic of oxovanadium(IV) species (Rangel, et al., 2001; Klich, 1996; Katoh, 2000).
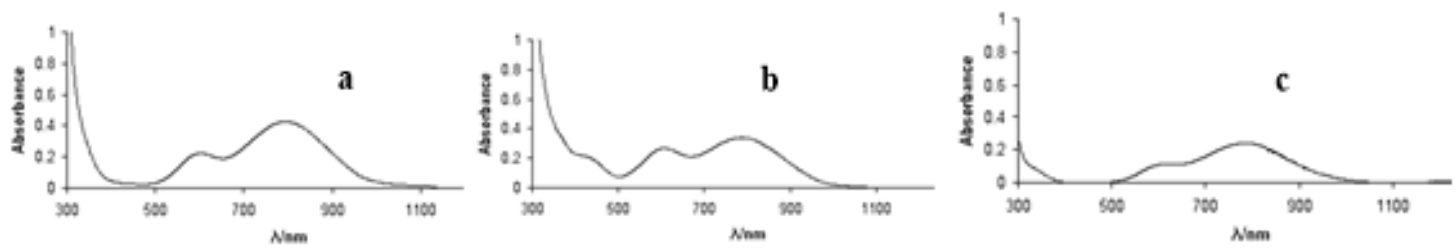

Figure 1. Visible absorption spectra of the complexes:(a) $\left[\mathrm{V}^{\mathrm{IV}} \mathrm{O}(\mathrm{GlyH})(\mathrm{Gly})\right]^{+} \mathrm{ClO}_{4}^{-} \cdot \mathrm{H}_{2} \mathrm{O}$ (1), (b) $\left[\mathrm{V}^{\mathrm{IV}} \mathrm{O}(\mathrm{GlyH})(\mathrm{Gly})\right]^{+} \mathrm{NO}_{3}{ }^{-} \cdot \mathrm{H}_{2} \mathrm{O}(\mathbf{2})$ and (c) $\left[\mathrm{V}^{\mathrm{IV}} \mathrm{O}(\mathrm{GlyH})(\mathrm{Gly})\right]^{+} \mathrm{CH}_{3} \mathrm{COO}^{-} \cdot \mathrm{H}_{2} \mathrm{O}(\mathbf{3})$ in anaerobic DMSO solution; [V] = $15.0 \mathrm{mmol}, \mathrm{pH} 4.84$. 
A general summary of the spectral characteristic of various oxo-ligand complexes of oxovanadium(IV) has been published (Ballhausen and Gray, 1962; Jorgensen, 1957). In general, all of the complexes appear to be strikingly similar: each show one band at about $13,000 \mathrm{~cm}^{-1}(770 \mathrm{~nm})$, followed by a somewhat less intense band at about $16,000 \mathrm{~cm}^{-1}(630 \mathrm{~nm})$ (Tomiyasu and Gordon, 1973). Interestingly, the present observations are resembling closely in indicating the presence of the oxovanadium(IV) species in solution.

Though ${ }^{1} \mathrm{H}$ NMR spectrum of paramagnetic complexes are less informative even then singlets for methylene protons have been identified for those paramagnetic vanadium(IV) complexes. Thus ${ }^{1} \mathrm{H}$ NMR spectrum of the complexes $\left[\mathrm{V}^{\mathrm{IV}} \mathrm{O}(\mathrm{GlyH})(\mathrm{Gly})\right]^{+} \mathrm{ClO}_{4}{ }^{-} \cdot \mathrm{H}_{2} \mathrm{O} \quad(\mathbf{1}), \quad\left[\mathrm{V}^{\mathrm{IV}} \mathrm{O}(\mathrm{GlyH})(\mathrm{Gly})\right]^{+} \mathrm{NO}_{3}{ }^{-}$ . $\mathrm{H}_{2} \mathrm{O}$ (2) and $\left[\mathrm{V}^{\mathrm{IV}} \mathrm{O}(\mathrm{GlyH})(\mathrm{Gly})\right]^{+} \mathrm{CH}_{3} \mathrm{COO}^{-} \cdot \mathrm{H}_{2} \mathrm{O}$ (3) show the singlet at around $\delta$ 4.83-4.84 ppm and at $\delta 5.75 \mathrm{ppm}$ can be assigned to four methylene protons. The higher chemical shift value means downfield shift of these protons can be attributed to their neighboring carbonyl groups. The anomeric effect of the vicinal $\mathrm{C}=\mathrm{O}$ group would be the reasoning of the downfield shift. There were no signals found for the $\mathrm{N}-\mathrm{H}$ protons probably due to their labile nature.

The cumulative assignment of the spectroscopic results can be envisaged the following chemical structures of the complexes in Figure 2.

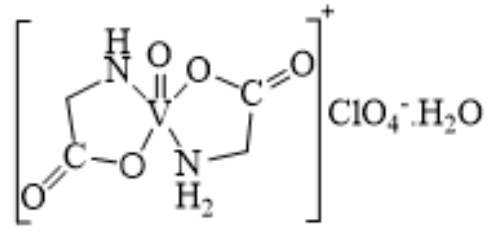

(1)

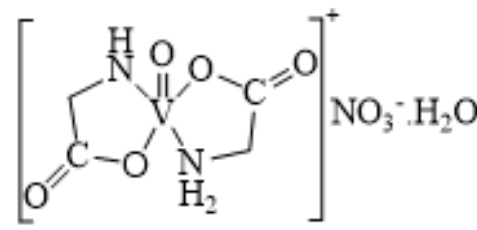

(2)

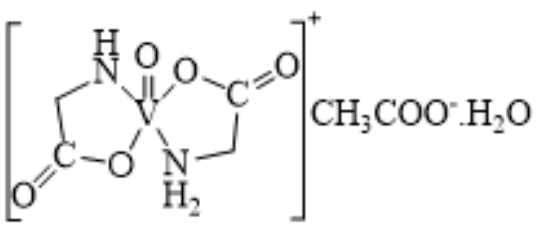

(3)

Figure 2. Proposed chemical structure of the complexes $\left[\mathrm{V}^{\mathrm{IV}} \mathrm{O}(\mathrm{GlyH})(\mathrm{Gly})\right]^{+} \mathrm{ClO}_{4}{ }^{-} \cdot \mathrm{H}_{2} \mathrm{O}(\mathbf{1})$, $\left[\mathrm{V}^{\mathrm{IV}} \mathrm{O}(\mathrm{GlyH})(\mathrm{Gly})\right]^{+} \mathrm{NO}_{3}{ }^{-} \cdot \mathrm{H}_{2} \mathrm{O}(2)$ and $\left[\mathrm{V}^{\mathrm{IV}} \mathrm{O}(\mathrm{GlyH})(\mathrm{Gly})\right]^{+} \mathrm{CH}_{3} \mathrm{COO}^{-} \cdot \mathrm{H}_{2} \mathrm{O}(3)$.

\section{Biological activities}

\section{Antibacterial activity}

Assessments of antibacterial activities of biogenic chelator, glycine and their corresponding oxovanadium(IV) complexes were carried out against pathogenic bacteria Shigella boydii, Shigella dysenteriae, Salmonella typhi and $E$ coli by disc diffusion method at three different concentrations (a: 2 $\mathrm{mg} / \mathrm{mL}$, b: $1 \mathrm{mg} / \mathrm{mL}$ and c: $0.5 \mathrm{mg} / \mathrm{mL}$ ) and compared with the standard Ciprofloxacin $(10 \mu \mathrm{g} / \mathrm{disc})$ antibiotic disc. The results showed that the solvent, DMSO; salt, $\mathrm{VOSO}_{4}$; ligand, glycine as well as the complexes, $\left[\mathrm{V}^{\mathrm{IV}} \mathrm{O}(\mathrm{GlyH})(\mathrm{Gly})\right]^{+} \mathrm{ClO}_{4}{ }^{-} \cdot \mathrm{H}_{2} \mathrm{O}, \quad\left[\mathrm{V}^{\mathrm{IV}} \mathrm{O}(\mathrm{GlyH})(\mathrm{Gly})\right]^{+} \quad \mathrm{NO}_{3}{ }^{-} \cdot \mathrm{H}_{2} \mathrm{O}$ and $\left[\mathrm{V}^{\mathrm{IV}} \mathrm{O}(\mathrm{GlyH})(\mathrm{Gly})\right]^{+} \mathrm{CH}_{3} \mathrm{COO}^{-} \cdot \mathrm{H}_{2} \mathrm{O}$, have no activity against the gramnegative bacteria Salmonella typhi, Shigella dysenteriae, Shigella boydii and 
Escherichia coli at the said concentrations. The results have been compared with commercially important bactericidal cipofloxacin. The inhibition by different complexes is also shown by Figure 3.

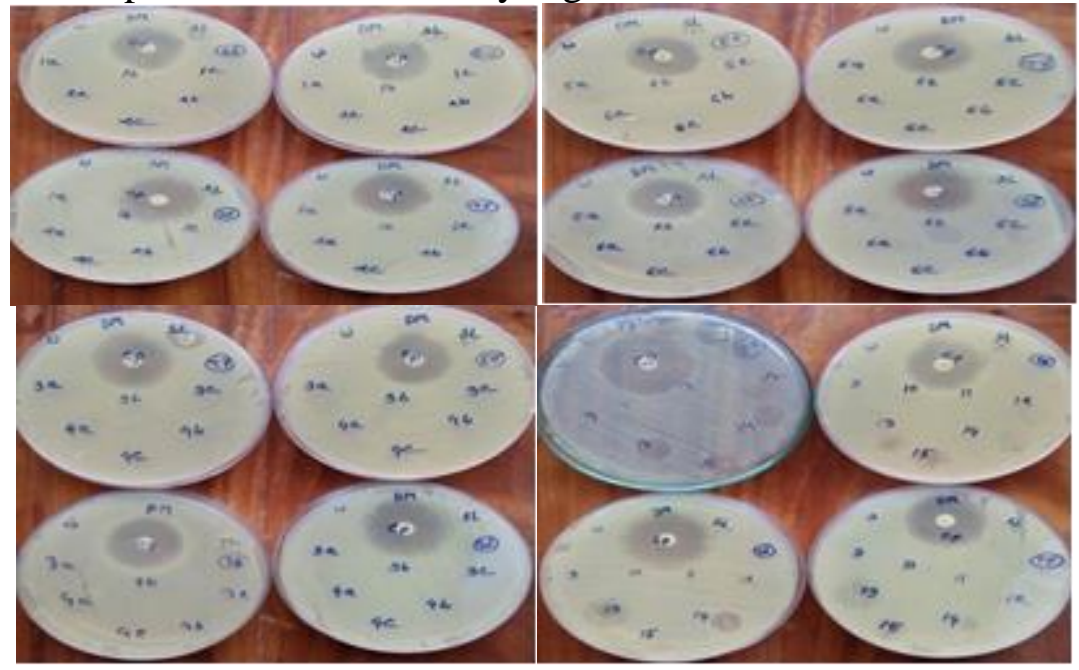

Figure 3. Antibacterial activity of complexes against Salmonella typhi, Shigella dysenteriae, Shigella boydii and Escherichia coli.

\section{Antifungal activity}

The antifungal activities of the biogenic chelator glycine and their oxovanadium(IV) complexes were studied against the selective fungi, Aspergillus niger, Penicillium notatum and Candida tropicalis by disc diffusion method in potato dextrose agar (PDA) media and compared with the standard antifungal drug griseofulvin $(5 \mu \mathrm{g} /$ disc $)$.

The Table 2 depicts the antifungal activities of the complexes. It is clear that all the complexes were inactive against Candida tropicalis but show good activity against fungi Aspergillus niger and Penicillium notatum. From the data we can explicitly say that the inhibition of mycelial growth decreases with decline of the concentration of the compounds as expected. In case of Aspergillus niger, the complex $\left[\mathrm{V}^{\mathrm{IV}} \mathrm{O}(\mathrm{GlyH})(\mathrm{Gly})\right]^{+} \mathrm{CH}_{3} \mathrm{COO}^{-} \cdot \mathrm{H}_{2} \mathrm{O}(3)$ show highest activity $(13 \mathrm{~mm})$ compared to the complexes $\left[\mathrm{V}^{\mathrm{IV}} \mathrm{O}(\mathrm{GlyH})(\mathrm{Gly})\right]^{+}$ $\mathrm{ClO}_{4}{ }^{-} \cdot \mathrm{H}_{2} \mathrm{O}(\mathbf{1})(12 \mathrm{~mm})$ and $\left[\mathrm{V}^{\mathrm{IV}} \mathrm{O}(\mathrm{GlyH})(\mathrm{Gly})\right]^{+} \mathrm{NO}_{3}{ }^{-} \cdot \mathrm{H}_{2} \mathrm{O}(2)(10 \mathrm{~mm})$. The complex (2) (with conc. $2 \mathrm{mg} / \mathrm{mL}$ ) exhibited the same activity as standard antifungal griseofulvin in case of fungus Penicillium notatum. The complexes (1) and (3) also show a significant activity (12 $\mathrm{mm}$ and $14 \mathrm{~mm}$ respectively) against it (Penicillium notatum). 
Table 2. The in-vitro antifungal activity of salt, ligand and their complexes.

\begin{tabular}{|c|c|c|c|}
\hline \multirow{2}{*}{$\begin{array}{c}\text { Complexes and } \\
\text { other } \\
\text { components } \\
\end{array}$} & \multicolumn{3}{|c|}{ Zone of inhibition (mm) } \\
\hline & Aspergillus niger & Penicillium notatum & Candida tropicalis \\
\hline DMSO & - & - & - \\
\hline $\mathrm{VOSO}_{4}$ & - & - & - \\
\hline Glycine & - & - & - \\
\hline $1 \mathrm{a}$ & 12 & 12 & - \\
\hline $1 b$ & 10 & 10 & - \\
\hline 1c & 8 & 9 & - \\
\hline $2 \mathrm{a}$ & 10 & 15 & - \\
\hline $2 b$ & 9 & 13 & - \\
\hline $2 c$ & 7 & 10 & - \\
\hline $3 a$ & 13 & 14 & - \\
\hline $3 b$ & 11 & 12 & - \\
\hline $3 c$ & 8 & 10 & - \\
\hline $\begin{array}{l}\text { Griseofulvin } \\
(5 \mu \mathrm{g} / \text { disc })\end{array}$ & 16 & 15 & 16 \\
\hline
\end{tabular}
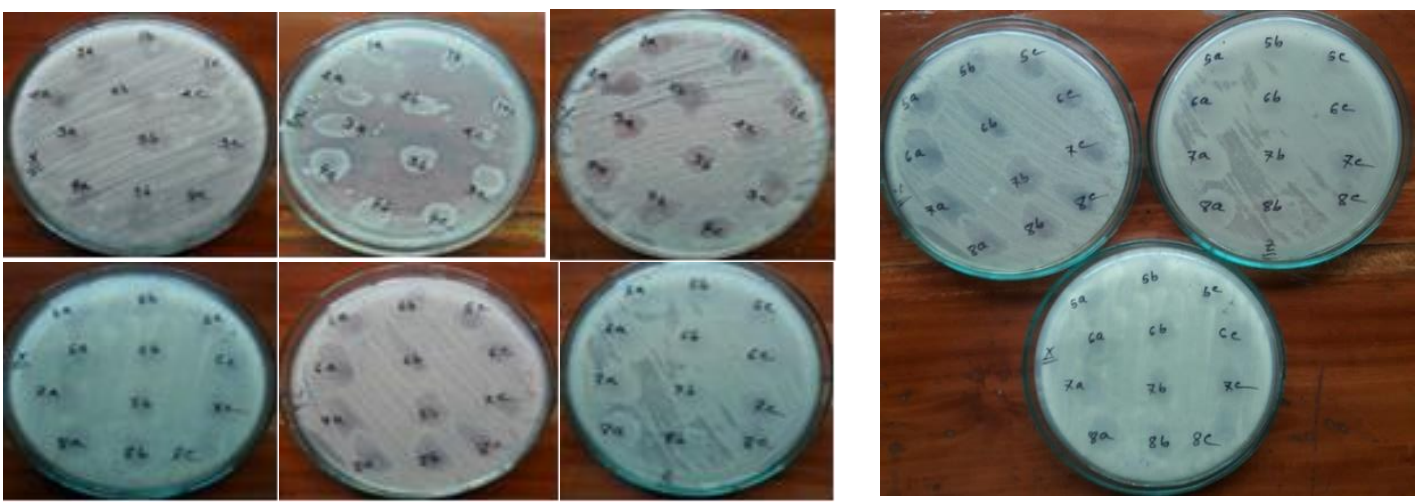

Figure 4. Antifungal activity of complexes against $\mathrm{X}=$ Aspergillus niger, $\mathrm{Y}=$ Penicillium notatum, $\mathrm{Z}=$ Candida tropicalis)

\section{Cytotoxic bioassay (in vitro)}

The vanadyl complexes were screened for their cytotoxic (brine shrimp bioassay) activity using (Meyer et. al., 1982; Finney, 1971) protocol. It is shown from the data recorded in Table 3 that all the complexes possess potent cytotoxicity. 
Table 3. The in-vitro cytotoxicity of the oxovanadium(IV) complexes.

\begin{tabular}{cccccc}
\hline \multirow{2}{*}{$\begin{array}{c}\text { Compounds } \\
\text { ID }\end{array}$} & \multicolumn{2}{c}{ After 4 hours } & \multicolumn{2}{c}{ After 8 hours } & \multirow{2}{*}{ Remarks } \\
\cline { 2 - 4 } & Dead & Live & Dead & Live & \\
\hline $\mathrm{H}_{2} \mathrm{O}$ with & 0 & 10 & 0 & 10 & Not cytotoxic \\
$3.8 \% \mathrm{NaCl}$ & & & & \\
$\mathrm{DMSO}$ & 0 & 10 & 0 & 10 & Not cytotoxic \\
$\mathbf{1 a}$ & 10 & 0 & NA & NA & Highly cytotoxic \\
$\mathbf{1 b}$ & 10 & 0 & NA & NA & Highly cytotoxic \\
$\mathbf{1 c}$ & 10 & 0 & NA & NA & Highly cytotoxic \\
$\mathbf{2 a}$ & 10 & 0 & NA & NA & Highly cytotoxic \\
$\mathbf{2 b}$ & 10 & 0 & NA & NA & Highly cytotoxic \\
$\mathbf{2 c}$ & 10 & 0 & NA & NA & Highly cytotoxic \\
$\mathbf{3 a}$ & 10 & 0 & NA & NA & Highly cytotoxic \\
$\mathbf{3 b}$ & 10 & 0 & NA & NA & Highly cytotoxic \\
$\mathbf{3 c}$ & 10 & 0 & NA & NA & Highly cytotoxic \\
\hline
\end{tabular}

N.B. a: $2 \mathrm{mg} / \mathrm{mL}$; b: $1 \mathrm{mg} / \mathrm{mL}$; c: $0.5 \mathrm{mg} / \mathrm{mL}$; 1 : $\left[\mathrm{V}^{\mathrm{IV}} \mathrm{O}(\mathrm{GlyH})(\mathrm{Gly})\right]^{+} \mathrm{ClO}_{4}{ }^{-} \cdot \mathrm{H}_{2} \mathrm{O} ; 2$ :

$\left[\mathrm{V}^{\mathrm{IV}} \mathrm{O}(\mathrm{GlyH})(\mathrm{Gly})\right]^{+} \mathrm{NO}_{3}{ }^{-} \cdot \mathrm{H}_{2} \mathrm{O}$ and 3: $\left[\mathrm{V}^{\mathrm{IV}} \mathrm{O}(\mathrm{GlyH})(\mathrm{Gly})\right]^{+} \mathrm{CH}_{3} \mathrm{COO}^{-} \cdot \mathrm{H}_{2} \mathrm{O}$.

\section{Conclusion}

The novel oxovanadium(IV) complexes, $\left[\mathrm{V}^{\mathrm{IV}} \mathrm{O}(\mathrm{GlyH})(\mathrm{Gly})\right]^{+} \mathrm{ClO}_{4}{ }^{-}$ $. \mathrm{H}_{2} \mathrm{O} \quad(\mathbf{1}), \quad\left[\mathrm{V}^{\mathrm{IV}} \mathrm{O}(\mathrm{GlyH})(\mathrm{Gly})\right]^{+} \mathrm{NO}_{3}{ }^{-} \cdot \mathrm{H}_{2} \mathrm{O} \quad$ (2) and $\left[\mathrm{V}^{\mathrm{IV}} \mathrm{O}(\mathrm{GlyH})(\mathrm{Gly})\right]^{+} \mathrm{CH}_{3} \mathrm{COO}^{-} \cdot \mathrm{H}_{2} \mathrm{O}(3)$ have been synthesized and their structures were determined by FT-IR, UV-Vis and ${ }^{1} \mathrm{H}$ NMR spectroscopic measurements. From the cumulative spectroscopic assessment it was envisaged that, the complexes adopt a square pyramidal structure, in which the two glycine ligands coordinate to vanadium(IV) center in bidentate fashions conforming a homoleptic structure. The amino nitrogen and a carboxylato oxygen atom coordinate the vanadium(IV) center from both sides making a five members chelate by each side. The complexes are stable in amorphous state and in aerobic and anaerobic solution. As far as our knowledge, these homoleptic bis(glycinato) oxovanadium(IV) complexes employing various counter anions are the first examples with biogenic glycine ligand. Significantly, the complexes $\left[\mathrm{V}^{\mathrm{IV}} \mathrm{O}(\mathrm{GlyH})(\mathrm{Gly})\right]^{+} \mathrm{ClO}_{4}{ }^{-} \cdot \mathrm{H}_{2} \mathrm{O}$ (1), $\left[\mathrm{V}^{\mathrm{IV}} \mathrm{O}(\mathrm{GlyH})(\mathrm{Gly})\right]^{+} \mathrm{NO}_{3}{ }^{-} \cdot \mathrm{H}_{2} \mathrm{O}(\mathbf{2})$ and $\left[\mathrm{V}^{\mathrm{IV}} \mathrm{O}(\mathrm{GlyH})(\mathrm{Gly})\right]^{+} \mathrm{CH}_{3} \mathrm{COO}^{-} \cdot \mathrm{H}_{2} \mathrm{O}$ (3) have the antifungal activities against Aspergillus niger and Penicillium notatum but ineffective against Candida tropicalis. These complexes have no antibacterial activity against tested bacteria. Unfortunately, the complexes were found cytotoxic against brine shrimp bioassay. 


\section{Acknowledgement}

The authors gratefully acknowledge the Ministry of Science and Technology, People's Republic of Bangladesh, for the financial assistance for this work by the special allocation fund (SAF): Grant no. PHY'S-375. Authors also would like to gratefully acknowledge the Wazed Miah Science Research Centre, Jahangirnagar University, Bangladesh for their immense help during the ${ }^{1} \mathrm{H}$ NMR spectroscopic measurements and elemental analyses of the complexes. Authors' hearty thanks will go to Dr. Kaisar Ali Talukder, former senior scientist and Head, Enteric Bacteriology Laboratory, Laboratory Science and Services Division, ICDDRB, for his supreme help and providing the necessary bacterial strains.

\section{References:}

1. Ackarmann, M. N. (1970). Infrared spectrometry of inorganic salts a general chemistry experiment. J. Chem. Edu., 47, 69-70.

2. Agarwal, R. K., Chakraborti, I. \& Sharma, S. K. (1994). Synthesis and characterization of oxovanadium(iv) complexes of schiff-bases derived from 4-aminoantipyrine. Polish J. Chem., 68(6), 1085-1092.

3. Amit, R., Y., Vijaya, V. D. \& Anand, S. A. (2010). Synthesis, characterization, electrical and biological studies of $\mathrm{VO}(\mathrm{IV})$, $\mathrm{MoO}_{2}(\mathrm{VI}), \mathrm{WO}_{2}(\mathrm{VI}), \mathrm{Th}(\mathrm{IV})$ and $\mathrm{UO}_{2}(\mathrm{VI})$ complexes with hydrazone ligand. Rev. Roum. Chim., 55(9), 537- 542.

4. Asma, I. E. S., Amna, S. A. Z., Mahmoud, S. E. M., Aref, A. A. \& Omar, F. M. (2001). Coordination properties of some mixed amino acid metal complexes. Synth. React. Inorg. Met-Org Chem., 31(4), 633-648.

5. Ballhausen, C. J. \& Gray, H. B. (1962). The electronic structure of the vanadyl ion. Inorg. Chem., l(1), 111-122.

6. Bhattacharjee, M., Chaudhuri, M. K., Islam, N. S. \& Paul, P. C. (1990). Synthesis, characterisation and physicochemical properties of peroxovanadium(V) complexes with glycine as the hetero-ligand. Inorg. Chim. Acta., 169, 97-100.

7. Bruijnincx, P. C. \& Sadler, P. J. (2008). New trends for metal complexes with anticancer activity. Curr. Opin. Chem. Biol., 12, 197206.

8. Budaiasih, K. S., Anwar, C., Santosa, S. J. \& Ismail, H. (2013). Synthesis and characterization of chromium (III) complexes with Lglutamic Acid, glycine and L-cysteine. J. Biolog. Biomol. Agar. F. Biotech. Engg., 7, 458-462.

9. Chidambaram, M. V. \& Bhattacharya, P. K. (1970). J. Indian Chem. Soc., 47, 881. 
10. Chohan, Z. H., Arif, M., Akhtar, M. A. \& Supurean, C. T. (2006). Metal-based antibacterial and antifungal agents: synthesis, characterization, and in vitro biological evaluation of $\mathrm{Co}(\mathrm{II}), \mathrm{Cu}(\mathrm{II})$, $\mathrm{Ni}(\mathrm{II})$, and $\mathrm{Zn}$ (II) complexes with amino acid-derived compounds. Bioinorg. Chem. Appl., 13, 83131.

11. Di Bernardo, P., Tomat, G., Zanonata, P., Portanova, R. \& Tolazzi, M. (1988). Thermodynamics of vanadyl(IV)-carboxylate complex formation in aqueous solution. Inorg. Chim. Acta, 145(2), 285-288.

12. Fabian, I. \& Nagypal. I. (1982). NMR relaxation studies in solutions of transition metal complexes VI. equilibria and proton exchange processes in aqueous solutions of $\mathrm{VO}^{2+}$-glycine system. Inorg. Chim. Acta, 62, 193-199.

13. Finney, D. J. (1971). Probit analysis, $3^{\text {rd }}$ edn. Cambridge University Press, Cambridge, London.

14. Garoufis, A., Hatiris, J. \& Hadjiliadis, N. (1991). Ternary complexes of $\mathrm{Pt}(\mathrm{II})$ with guanosine and amino acids of the type trans$\left[(\text { guo })_{2} \mathrm{Pt}(\mathrm{amacH})_{2}\right] \mathrm{Cl}_{2}$, where amacH is glycine, L-Alanine, $\mathrm{L}-\mathrm{V}$ aline, and L-Isoleucine. J. Inorg. Biochem., 41, 195-203.

15. Gehad, G. M., Hanan, F. A. E. H., Maher, M. I. E. D. \& Walaa, H. M. (2011). Synthesis and characterization of mixed ligand complexes of lomefloxacin drug and glycine with transition metals. Antibacterial, antifungal and cytotoxicity studies. J. Mol. Struct., 999, 29-38.

16. Grecu, I., Sandulescu, R. \& Neamtu, M. (1986). Complexes of Cu(II) and $\mathrm{Mn}(\mathrm{II})$ with acylated amino acids. Rev. Chim., 37(7), 589-595.

17. Guo, Z. \& Sadler, P. J. (1999). Medicinal inorganic chemistry, Advances in inorganic chemistry. 49, 183-306.

18. Husseiny, A. F., Aazam, E. S. \& Al Shebary J. (2008). Synthesis, characterization and antibacterial activity of Schiff-base ligand incorporating coumarin moiety and it metal complexes. Inorg. Chem., $3(1), 64-68$.

19. Islam, M. K., Kanamori, K. \& Hossain, M. M. (2011). Synthesis and spectroscopic properties of the first homoleptic histidine complex of vanadium(IV) $\left[\mathrm{V}^{\mathrm{IV}} \mathrm{O}\right.$ (L-his)(L-Hhis) $] \mathrm{ClO}_{4} \cdot \mathrm{H}_{2} \mathrm{O}$. J. Bangladesh Chem. Soc., 24(1), 1-8.

20. Jorgensen, C. K. (1957). Acta Chem. Scand., 11, 73.

21. Katoh, A., Taguchi, K., Okada, H., Harata, M., Fujisawa, Y., Takino, T. \& Sakurai, H. (2000). Chem. Lett., 29(8), 866.

22. Klich, P. R., Daniher, A. T., Challen, P. R., McConville, D. B. \& Youngs, W. J. (1996). Vanadium(IV) Complexes with Mixed O,S Donor Ligands. Syntheses, structures, and properties of the anions Tris(2-mercapto-4 methylphenolato)vanadate(IV) and Bis(2mercaptophenolato)oxovanadate(IV). Inorg. Chem., 35(2), 347-356. 
23. Kostova, I. (2006). Platinum complexes, as anticancer agents. Recent Pat. Anti-Cancer Drug Discovery, 1, 1-22.

24. Leary, J. A., Zhou, Z., Ogden, S. A. \& Williams, T. D. (1990). Investigations of gas-phase lithium -peptide adducts: tandem, mass spectrometry and semiempirical studies. J. Am. Soc. Mass Spectrom., 6, 473-480.

25. Maythalony, B. A., Mehboob, M. M., Wazeer, M. I. M., Isab, A. A., Shaikh, M. N. \& Altuwaijri, S. (2013). Synthesis, CP-MAS NMR characterization, and antibacterial activities of glycine and histidine complexes of $\mathrm{Cd}(\mathrm{SeCN})_{2}$ and $\mathrm{Hg}(\mathrm{SeCN})_{2}$. Bioinorg. Chem. Appl., 2013, 1-8.

26. Meyer, B. N., Ferrigni, N. R., Putnam, J. E., Jacobsen, L. B., Nichols, D. E. \& McLaughlin, J. L. (1982). Brine shrimp: A convenient general bioassay for active plant constituents. J. Med. Plant Res., 45, 31-34.

27. Miller, F. A. \& Wilkins, C. H. (1952). Infrared spectra and characteristic frequencies of inorganic ions, their use in qualitative analysis. Anal. Chem., 24(8), 1253-1294.

28. Nakamoto, K. (2009). Complexes of amino acids. Infrared and raman spectroscopy of inorganic and coordination compounds: applications in coordination, organometallics and bioinorganic chemistry. John $6^{\text {th }}$ Ed.; Wiley and Sons: United states. 67-69.

29. Negoiu, M., Rosu, T., Saramet, I. \& Matei, C. A. (2005). Complexes of $\mathrm{Cu}(\mathrm{II})$ and $\mathrm{Mn}(\mathrm{II})$ with acylated amino acids derived from glycine and $\alpha$-alanine. Analele Universitătii din Bucuresti-Chimie, Anul XIV (serie nouă), I-II, 129-133.

30. Nomiya, K. \& Yokoyama, H. (2002). Syntheses, crystal structures and antimicrobial activities of polymeric silver(I) complexes with three amino acids [aspartic acid $\left(\mathrm{H}_{2} \mathrm{asp}\right)$, glycine (Hgly) and asparagine (Hasn)]. J. Chem. Soc., Dalton Trans., 2483-2490.

31. Orvig, C. \& Abrams, M. J. (1999). Medicinal inorganic chemistry: introduction. Chem. Rev., 99, 2201-2204.

32. Osunlaja, A. A., Ndahi1 N. P. \& Ameh, J. A. (2009). Synthesis, physico-chemical and antimicrobial properties of $\mathrm{Co}(\mathrm{II}), \mathrm{Ni}(\mathrm{II})$ and $\mathrm{Cu}$ (II) mixed-ligand complexes of dimethylglyoxime - Part I. Afr. J. Biotechnol., 8(1), 4-11.

33. Pesch, F. J., Prent, H. \& Lippert, B. (1990). Mixed nucleobase, amino acid complexes of $\mathrm{Pt}(\mathrm{II})$. Preparation and $\mathrm{x}$-ray structure of trans$\left[\left(\mathrm{CH}_{3} \mathrm{NH}_{2}\right)_{2} \mathrm{Pt}\left(1-\mathrm{MeC}-\mathrm{N}_{3}\right)(\mathrm{gly}-\mathrm{N})\right] \mathrm{NO}_{3} \cdot 2 \mathrm{H}_{2} \mathrm{O}$ and its precursor trans$\left[\left(\mathrm{CH}_{3} \mathrm{NH}_{2}\right)_{2} \mathrm{Pt}\left(1-\mathrm{MeC}-\mathrm{N}_{3}\right) \mathrm{Cl}\right] \mathrm{Cl} \cdot \mathrm{H}_{2} \mathrm{O}$. Inorg. Chim. Acta, 169, $195-$ 200.

34. Rabindra, R. P. \& Sudhakar, K. (1990). Indian J. Chem., A29, 1182. 
35. Rabindra, R. P. \& Raviprakash R. M. (1991). Indian J. Chem., A30, 1182.

36. Rangel, M., Tamura, A., Fukushima, C. \& Sakurai, H. (2001). In vitro study of the insulin-like action of vanadyl-pyrone and -pyridinone complexes with a $\mathrm{VO}(\mathrm{O} 4)$ coordination mode. J. Biol. Inorg. Chem., 6(2), 128-132.

37. Sabat, M., Satyashur, K. A. \& Sundaralingam, M. (1983). Ternary complexes as models for protein-metal-nucleic acid interactions: structure of palladium(II) complex with glycyl-L-tyrosine and cytidine. J. Am. Chem. Soc., 105, 976-980.

38. Sharma, R. (2013). Synthesis, characterization and antimicrobial activity of bis( $\gamma$-aminobutyrohydroxomate)oxovanadium(IV). Asain J. Adv. Basic Sci., 1(1), 45-50.

39. Sharma, S. \& Sharma, N. (2013). Synthesis, characterization, electrochemistry and antimicrobial activities of bis(hydroxamato)oxidovanadium (IV) complexes. Chem. Sin., 4(3), 108-119

40. Sigel, H., Fisher, B. E. \& Farkas, S. (1983). Ternary complexes in solution. 42. Metal ion promoted hydrophobic interactions between nucleotides and amino acids. Mixed-ligand adeonsine 5'triphosphate/metal ion(II)/L-leucinate systems and related ternary complexes. Inorg. Chem., 22, 925-934.

41. Temitayo, A., Isaac, O. \& Olugbena, A. (2012). Structural and antimicrobial studies of coordination compounds of phenylalanine and glycine. J. Chem., 4(2), 49-59.

42. Tomiyasu, H. \& Gordon, G. (1973). Stability constants for the oxovanadium(IV)-glycine system in aqueous solution. J. Coord. Chem., 3, 47-56.

43. Williams, P. A. M. \& Baran, E. J. (1997). $\left[\mathrm{VO}(\mathrm{His})_{4}\right] \mathrm{SO}_{4} \cdot 2 \mathrm{H}_{2} \mathrm{O}$, the first isolated oxovanadium(IV) complex of an essential amino acid. Transition Met. Chem., 22, 589-591.

44. Zhang, C. X. \& Lippard, S. J. (2003). New metal complexes as potential therapeutics. Curr. Opin. Chem. Biol., 7(4), 481-489. 